\title{
New Cities In Urban And Regional Development Planning Oyesiku K; Lagos, Nigeria. Longman (2010) Pp 353. Isbn 9789780263577 (Paper Back) Includes Index, Photos, Notes, Tables And Figures, Appendix And References. Price N1,500.00. Approx. \$10.00.
}

\author{
Mohammed Olaitan Lawal \\ Received: 25112013 / Accepted: 1112 2013 / Published online: 30062014 \\ (C) 2014 Faculty of Geography UGM and The Indonesian Geographers Association
}

\begin{abstract}
For a long time, cities have been regarded as the main source of economic growth and development. However, increased size and density of cities have generated high land costs, rent and transport cost, congestion and pollution, and increased social disorganization. The condition is even worse in developing countries - urban migration, over-utilization of housing and infrastructure, persistent slums, and squatter settlements. This books represents a comparative study between the USA and Nigeria related to characteristics of the cities in both countries. This book tries to address the question "How has the United States of America and Nigeria have been able to address the problems of 'swollen' cities and metropolitan growth?". Outcome of several planned new communities and cities in both countries is of paramount importance to the contribution of knowledge on physical planning approaches globally. The most significant discussion are shown in the final chapter, by giving examples of policy implications and comments on new cities in national and regional development as well as urban and regional development and planning strategy in the global context.
\end{abstract}

Keywords: Cities, development planning, Nigeria, USA.

Abstrak Untuk waktu yang sangat lama, kota telah dianggap sebagai sumber utama pertumbuhan ekonomi dan pembangunan. Namun, peningkatan ukuran dan kepadatan kota telah berdampak pada tingginya harga tanah, biaya sewa dan transportasi, kemacetan dan polusi, serta disorganisasi sosial. Kondisi yang lebih lebih buruk terjadi di negara-negara berkembang - migrasi perkotaan, pemanfaatan lahan permukiman dan infrastruktur secara berlebihan, serta permukiman kumuh dan ilegal. Buku ini menyajikan studi perbandingan antara Amerika Serikat dan Nigeria berkaitan dengan karakteristik kota-kota di kedua negara tersebut. Buku ini mencoba untuk menjawab pertanyaan "Bagaimana Amerika Serikat dan Nigeria mengatasi masalah kota yang menjadi semakin besar dan pertumbuhan metropolitan?”. Hasil dari beberapa perencanaan dari kotakota di kedua negara sangat penting terkait kontribusi pengetahuan tentang pendekatan perencanaan fisik secara global. Pembahasan yang signifikan ditunjukkan dalam bab terakhir yang menyajikan contoh-contoh implikasi kebijakan dalam pengelolaan kota terkait pembangunan nasional dan daerah serta pengembangan dan perencanaan strategi kota dan regional dalam konteks global.

Kata kunci: Perkotaan, perencanaan pembangunan, Nigeria, Amerika Serikat

\section{Introduction}

There are Nine major chapters in this book covering 353 pages. By a way of prolegomena, chapter one begins with the study of New cities, its rate of growth as well as the proportion of people living in the cities in recent years. Cities of economic strength for the surrounding regions as well as places of power, development innovations and modern culture.

M.O. Lawal

Departement of Geography and Planning, Faculty of Social Sciences Lagos State University

E-mail: mohammedolawal@yahoo.com
In this regard, cities have also been regarded as the "engine" of economic growth and development according to the author. The complexity of cities have been described by Lewis Mumford when he said that "nobody can be satisfied with the form of the city of today". Neither as a working mechanism, as a social medium, nor as a work of art does the city fulfil the high hopes that modern civilization has called forth-or-even met reasonable demands.

In the developed countries, increased size and density of cities have generated among other diseconomies; 
high land costs; rent and transport cost; congestion and pollution effects; poor health and welfare increased social disorganization (increasing rates of delinquency, crime, insanity and poverty); social and economic stratification of the minorities; unemployment; homelessness; disequilibrium between city and suburbs; overcrowding; as well as sprawling and bulging of suburban areas.

The developing countries while sharing in some of the above are experiencing the following in addition to primary of growth, rural - urban migration, inadequacy and over-utilization of housing and basic services and infrastructure; persistent slums and squatter settlements; and lack of conscious physical planning as most cities grew from their traditional setting, and are caught up by modern development.

Lagos, the most populous city in Africa was described as a city of mixed blessings. In spite of its peculiar problems the city remains the economic life-wire of country's over 140 million people. Both the natural population growth, urban-urban and rural-urban migration are perhaps the most significant factor responsible for the alarming growth of Lagos. The phenomenal rate of the city's population growth is considered one of the fastest in the world.

Generally speaking, there is an acute shortage of land in Lagos. The interactable growth problems of the city were of such concern to the national government of Nigeria that it remarked in the mid-1970's that where land was readily available, the prices are often prohibitive and compensation claimed and paid by governments much higher than the true opportunity cost of land. Thus, the author was able to identify land problems in Lagos, p.2.

A comparison between Nigeria and the United States of America cities were used and made as case study. Lagos, Atlanta, San Antonio, Portland, NorfolkPortsmouth in their phenomenal growth over the years. In the US.; City annexation was recognized in which American-urban sprawl and the US. government response to the problem.

Urban scholars and city government politicians have described the images of American cities in different ways. They are considered positively as centres of culture and civility that represent a new and higher town of civilization; diversity in terms of race culture, classes, belief, centre of opulence, opportunities and hope, and centres of wealth, innovation, knowledge and technology. On the other hand, the same urbanization problems have caused American society to be described as a jungle hell, full of racial tension, anguish anger, grief, a place of disordered settlements where buildings are getting old and many things break down, and others need repairs, as well as cities consisting of a society in a state of decay where some people are still making money out of the state of disrepair.

Globally, cities are also described as places where the adjective "too" can be used to qualify every activity and problem, namely too noisy, too dusky, too smelly, too commercial, too crowded, and full of immigrants; too full of Jews, Irishmen, Italians and Poles, too artificial, too destructive of conservation, too destructive of communication, too greedy, too capitalistic, too full of automobiles, too full of smog; too full of dust; too heartland, too intellectual, too scientific, too destructive of family, tribal and patriot feeling.

In a similar vein, many American greatest thinker have viewed cities as dirty, dangerous and congested, homes of the unhealthy, the immoral and the foreign, in short sinkholes to be avoided, not treasures to be sought or even problems to be solved. The author described the problems that besiege many American cities such as race, class, ethnicity and culture and concluded that "decent people should not live here/city" because of the problems of being posed by cities. Cities are seen as growing in a formless spread of housing. The journey to work, shop, recreation, and worship as experienced in the 1960's and 1970's(p.4).

Cities growing in a formlessly manner. The situation in the developing countries is very precarious(p.4) with the pattern of public investments, over the years favouring the few urban centres to the neglect of rural areas and resulting in the depopulation of rural areas and pressure on infrastructure and services generally is indeed so great that a decline in quality and quantity of services is inevitable. Yet, urban centres and cities continue to grow and expand beyond the original planned capacity and corporate limits.

One question the Planners and those concerned with city built environment continuously ask is - Why not build a whole new city considering the fact that urban planning is concerned with ordering and design of settlement? What is the rationale for building "New Towns"? (p.5). The answers to the above questions could not be far-fetched as there was a dissatisfaction with city scenes by urban scholars in the late 19th century.

One physical planning strategy worldwide has been the building of "new towns" as a solution to the problems and as a panacea to metropolitan overspill effects and urban conurbation. Planning new towns and communities are also considered as a strategy of urban decentralization, industrial and employment dispersal, and an internal migration policy.

Urbanization as a process, as involving a guided concentration of people in settlements. New towns and new cities are now a policy issue in population redistribution matters and urban and regional development planning. The concept of the garden cities was pioneered by Ebenezer Howard as can be seen in the post-Industrial city of the 19th century based on the concept of Ebenezer Howard. There was integration of landuse planning and transportation planning with urban renewal, urban regeneration, city aesthetics, safety through design and standards, slums rehabilitation, sub-urbanization environmental protection and conservation and urban sustainability. 
The concept of sustainable development and sustainable cities in the 1980's have formed an important aspects of urban planning and its practice with a view to limiting overuse of natural resources, growing social inequality and large-scale climate change (p.6).

Ebenezer Howard's published "Garden Cities of Tomorrow" and his Garden City Movement in the 20th Century (p.10).

This book represents a comparative study between the USA and Nigeria. The author has rightly cautioned us that by saying that "Comparative studies, in whatever field are to be undertaken with caution". This is more so of the USA and Nigeria whose environments exhibit contrasting cultures and levels of socio-economic development. The USA is the leading world political and economic power while Nigeria belongs to the world classified as developing and a leading African country. As suggested by the author, phenomenon that are relational do not necessarily have to be identical in their absolute properties, the onus lies on the researcher to establish equivalents in similarities and differences for a successful study. These can be measured by the size of government and its size of government and its allocation of resources, national economic structure and level of wealth and well being among others as shown in table 1.1 (p.11) where the size of government and allocation of resources between the two countries.

In terms of the population of both countries, population figures estimated for the July 2005 (from the United Nations World Population Prospect,2004 Revision and among Median Fertility)showed that of the USA was estimated at 298 million people, making the country the third most populous country in the world after China (1.3 billion), India (1.1. billion). In the Nigerian case, the mid 2005 United Nations estimate was 132 million people making her the 9th ranked most populous country in the world.

Of interest is the rate of urbanization by country. While the USA was ranked the 20th most urbanized country in the world with urban population of $82 \%$ in 2008 and urbanization rate of $1.3 \%$ (2005-2010) estimates) Nigeria as at 2008 was ranked the 119th urbanized country in the world with urban population of $48 \%$ and urbanization rate of 2.8\% (2005-2010 estimates).

In terms of the national economic structures between the two countries, it was found that about $48 \%$ of labour force 1990-1992 were engaged in Agriculture in Nigeria while only $3 \%$ were engaged in Agriculture in the U.S. Within the same period, about $7 \%$ of the labour force were engaged in the industry for Nigeria while $25 \%$ of the labour force that were engaged in the industry in the U.S. Similarly, $45 \%$ of the labour force were engaged in the services while that of the US. was put at $72 \%$.

The wealth and well-being of a nation determines the quality of life of the citizens. Table 1.3 on p. 13 tries to compare the well-being of the USA. with Nigeria's well-being, where in virtually all cases of the USA. fared considerably better than that of Nigeria. Worthy of note is the geometric rate of growth of the population in contrast to the arithmetic growths of the economy as a whole. Nevertheless, the wide variation in spatial inequality in income and standard of living particularly between the urban and rural areas obscured the enormous wealth that is concentrated in the urban areas and cities in Nigeria.

The author was able to dwell further in his comparative analysis of the systems of government and administrative structures of the countries. It was noted that the USA became an independent nation more than two hundred years ago. It emerges as a confederation of states with enormous power concentrated in the states and local administration. The local governments have control on almost everything including landuse, primary and secondary education, parks, community, goods and services.

On the other hand, Nigeria may be considered a relatively young country, gaining its independence from the British just fifty years ago. From birth as a nation, Nigeria has remained a unitary country with a high concentration of power in the federal government and a loose federation of the states and local governments. The country emerged as a nation of three regions based on ethnicity and geographic location. As a way of decentralization of government, twelve states from four regions were created in 1967, and since then several of such exercise are continuously taking place giving the country its thirty six state structure and 594 local governments as at September 1996. At the moment, the country has a thirty-six state, and a federal capital territory structure and 774 local governments. In terms of physical planning administration, urban and regional planning has always been regional and state governments' affairs. Until the recent promulgated national and regional planning law that makes planning a function of the three tiers of government, the state governments were empowered to deal with issues pertaining to physical planning and establishing local agencies at the local level to oversee planning matters. In a way planning matters were over-concentrated at the state government levels, alienated from the majority that physical planning and development of sites and services, provision of urban services is a recent phenomenon in the country. Therefore, government has been the sole provider since independence, and with the concomitant unstable governments for decades it is imaginable the state of city and urban administration, and the efforts to decentralize and de-concentrate congested metropolitan areas of the country.

The frequency of changes in the administration and policies have affected not only national economy, the quality and standard of living of the people, but also policies related to spatial de-concentration and decentralization, as well as population control and settlements building. In many regions of these countries, cities are becoming inefficiently managed as diseconomies 
of scale and agglomeration started setting in. The question that has agitated one's mind is that "How has the United States of America and Nigeria have been able to address the problems of "swollen cities", metropolitan growth, and the outcome of several planned new communities and cities in both countries, is of paramount importance to the contribution of knowledge on physical planning approaches globally.

The rationale for the author's choice of the selected cities for comparative study in this book consisted of three planned new cities in the United States of America and four new cities in Nigeria as discussed in chapters 5,7 and 8 . The choice of cities for this study was preceded by reconnaissance visits to many planned new cities or communities in the USA. and Nigeria. It is interesting to note that during the visits to the cities selected by the author as case studies in both countries, references were often made to planned cities in Europe as well, particularly Milton Keynes in England, some references are made to the nature and success of Milton Keynes as one of the best planned cities in the world, particularly as one that reflects the garden city concept in chapter 9 . The visitation of the author to these cities is for him to have a feel or a kind of impulse of these cities and towns on a first hand information about these cities.

In the United States of America, major areas of extensive metropolitan growth and concentration of population also referred to as the 'Sunbelt regions which occur in the Southeastern and Southwestern corners of the country that shared similarities of economic development and demographic changes since 1940's. The Sunbelt West States are Washington, Oregon, California, Nevada, Utah, Arizona, Colorado, New Mexico, Oklahoma and Texas, while the Sunbelt South east include Florida, Georgia, South Carolina, North Carolina, Virginia, Delaware and Maryland as shown in figures s1.3 and 1.4 of the textbook. The Sunbelt States are those states that represents the areas within the past five decades in the history of the USA. that have been witnessing most rapid economic, commercial, financial and industrial growth at the state and city levels in contrast to other regions of the country. Figure 1.5 of the text depicits this illustration. Besides, the economic growth are concentrations of rapid urban growth and metropolitanization of the cities between 1940 and1970

For the analysis that is described in this book, three new cities were selected in the USA. The choice is basically selective based on the year of establishment and physical development of the cities and given consideration for regional spread within the "Sunbelt" regions. The cities that were considered for detailed studies and analysis include:- Columbia in Maryland; Reston City in Virginia State; and Irvine in California as illustrated and shown in figure 1.6.

Coming home to the Nigeria case, the author regarded this as being straight forward because, apart from the fact that the country is relatively young as an independent nation, the problems of rapid urban- ization and metropolitanization are just manifesting themselves in the country. Planning of cities in the modern sense is a recent phenomenon in the country. Four towns were chosen for detailed analysis on areas of concentration of metropolitan growth since 1960 and to a considerable extent regional spread. The four are Abuja, the nation's new capital city that was established partly to de-concentrate economic and population growth around Lagos metropolis; Victoria Garden City in Lagos; Ajoda New Town in Oyo State to disperse population away from Ibadan metropolitan area in Oyo State; and Gateway Paradise City, located in the heart of Ogun State which is just been developed as a strategy of spatial dispersal and developing intermediate cities.

Apart from the comparative analysis of these cities and towns in the USA and Nigeria, the author was able to educate his readers and taught them about Milton Keynes in England and Almere in the Netherlands. References were made to the Milton Keynes in particular as a result of its worldwide acceptance as one of the best planned and successfully developed planned new cities in the world.

This book is able to present an analysis of the study on new towns and cities from the physical planning perspectives. The principal focus is the application of the concept of new cities in both Nigeria and the USA., and on evaluation of the relative success or otherwise of the new cities development in both countries. The topics discussed was able to focus on a wide range of issues on city development and planning and, together, the chapters provided a composite picture of pre-industrial, post-industrial, and contemporary new cities and urban world in general. The nine chapters of the book has given inter-related views on planned new towns and communities starting with the prolegomenary chapter. The author also dwelt into a worldwide view on the major concepts that are the focus of the study. The other subsequent chapters examined the case studies.

Chapter 2 examines the different perspectives of definitions of towns, cities and new cities. This is to a view to arriving at some working definitions. The different views expressed on the meaning of new towns and planned new communities are also discussed in this chapter.

Chapter 3 looks at the conceptual clarification of new towns and planned new communities. The author was able to link all these up with the trend in urbanization and population growth in the global context. The chapter also discusses how and why urban centres, towns and cities emerge and develop across the globe and also examines the emergence of new cities since the beginning of the $21^{\text {st }}$ century as well as their main objectives at the initial period of their development.

The author was able to present to us in chapter 4 urbanization and sub-urbanization pattern in the United States of America how the cities and suburban have developed physically and their inherent peculiar problems. The main purpose of this is to provide some 
historical background that may be influencing the emergence of designated new cities and planned new communities in the country as succinctly discussed in chapter 5 , where the author was able to provide an insightful perspectives into the three selected contemporary new cities in the United States of America in terms of their justification, design objectives process of physical development, the roles and functions of public and private sectors in the implementation of different aspect of the plans and emerging issues on their growth. Their economic bases are also highlighted as well as evaluated against expected or anticipated achievements.

Chapter 6 considered the pattern of urbanization along some distinct periods of Nigeria's development. The overall goal of detailed discussions on urbanization is to highlight the relationship between urbanization and new cities development in the country.

In chapter 7, the general application of the concept of new towns in Nigeria, by drawing the conceptual exposition discussed in both chapters 2 and 3.One can easily see from this chapter that the chapter is not generally about new towns programme in Nigeria that would necessitate a comprehensive analysis and overview of all new cities in the country rather selected as case studies as already illustrated and discussed in chapter 1 .

The new towns in Nigeria that was discussed by the author include Abuja, the new federal capital and Victoria Garden City ( $V G C$ ), both emerging from Lagos metropolitan congestion. The chapter focuses its attention on new cities experiment in Nigeria and discusses various aspects of new cities peculiar to each of them in the same manner in which their counterparts in America have been studied and analyzed. Also, the chapter discusses the compelling reason and justification of the federal capital leaving Lagos city. Moreover, the chapter was able to highlight the development in Lagos itself as a way of drawing attention to the need for deconcentration of the metropolis serving both as a city, state and federal capital.

Chapter 8 represents a continuation of chapter 7 in terms of the detailed discussion of selected new cities in Nigeria by looking at other selected new cities from other parts of Nigeria. These include Ajoda New Town, located in proximity to Ibadan, the capital of Oyo State and the Gateway Paradise City located in the heart of Ogun State to spur development in that part of the state and, perhaps, the reinvigorate private developers' involvement in the development of infrastructure, particularly housing and liveable environment in the state. The details of these two case studies both in terms of site and situation, planning and growth, residential areas and housing, economic base and future growth are highlighted in this penultimate chapter.

Finally, chapter 9 epitomises the conceptual understanding of new towns and also a discourse of contemporary issues on and challenges of urban and city development, particularly the emergence of new communities either outside the metropolitan cities or in the regions, rural areas or lagging regions between main metropolitan regions. The policy implications and comments on new cities in national and regional development, and as urban and regional development, and as urban and regional development planning strategy in the global context are examined and fully discussed

Inspite of the thoroughness which the author has put or exhibited into this book, one cannot but observe some "printer's devil" and some word spelling mistakes as can be seen on p. 122 line 13. The word should read "an" acceptable plan for the city. Similarly, on p. 139 another mistake occurred in the process of the author's trying to describe Reston City under the sub-heading planning and growth line 1 . The source provided to table 6.3 did not bear the correct initial of Mabogunje, A.I. [1968] which is supposed to be Mabogunje A.L. [1968]. Also, on page 239, notes number 6, should read A Geography of Nigerian Development, Ibadan. On page 306 line 4 should read liveable on the note section. All these are just typographical errors which was perhaps caused by the printer's devil.

The author's regard for photographs taken being labeled as figure and also labeling diagrams also as figures, perhaps the author could have referred to these photographs as plates rather than figures. There is need to separate photographs from diagrams.

In addition to the general references provided by the author on pages 327 - 344, the author was able to provide additional footnotes at the end of every chapter of the book. The additional notes provided here would serve readers who may wish to do a research in New Cities in Urban and Regional Development Planning.

This book is an impeccable source of information, a reference point and knowledge for all Town Planners, Professors, Graduate students as well as all lovers of urban and regional planning. The explanations are pungent, lucid and coincise as it directly hits the nail on the head. In other words, the author goes directly to the explanations he wants to make. This is a book that should be read by everyone with any interest in contemporary New Cities in Urban and Regional Development Planning. Professor Oyesiku was able to portray how cities works or functions in both the Developed and the Developing Countries. Perhaps the author has tailored his findings to that of conceptualized by one of the American Planners in the 60's and 70's - Alan Jacobs - "Making City Work" and the "Image of the City" - Kelvin Lynch [1960].

Congratulations to Professor Kayode Oyesiku on his book on "New Cities in Urban and Regional Development Planning. Just like I found the book to be very interesting; I guess other readers would also find the book to be very interesting. "The taste of the pudding they say is always in the eating." I strongly recommend this book for all and sundry. 